It would be interesting to hear of further observations of this bright meteor. It must have been seen by many persons, as the night was very clear.

The fireball of February $2 \mathrm{r}, \mathrm{r} 865$, had a radiant at $255^{\circ}+55^{\circ}$, and close to that of the meteor of January 2 last, but the difference of date is too considerable to permit an inference that the wo bodies diverged from the same stream.

January 8.

W. F. Denning.

IN NATURE, November IO, p. 36 , it is stated in reference to a meteor that "a Norwegian astronomer" is of the opinion that the track of the meteor must have lain too high to be heard. "He calculates from the reports to hand that the bursting of the meteor occurred at an altitude of about 6000 feet $(\mathrm{sic})$, and he thinks that even this figure may be safely doubled."

It may interest some of your readers to know that on the night of July 3,1884 , at 8.27 p.m. standard time of the $75^{\text {th }}$ meridian, a meteor was seen by me, as well as by others, here, and about $5 \mathrm{~m}$. I $7 \mathrm{~s}$. afterwards a sound was heard something like distant thunder, except that it seemed to swell rapidly and steadily to a maximum intensity, and then diminish again in much the same way, but more slowly. I immediately connected the sound with the appearance of the meteor, and stated that it must have been a little over sixty miles distant, and from the estimated angle of elevation about thirty miles above the surface of the earth. This estimate was borne out by the accounts from other places of the course of the meteor. The sound I should be inclined to attritute to the rushing together of the air in the wake of the meteor, or perhaps more probably to the sudden c mpression of the air in front of it, and not to its bursting.

The following account of the meteor was given in the Canadian Weather Reviero of July 1884 ; - "A magnificent meteor was seen on the night of the 3 rd at $8.27 \mathrm{p} . \mathrm{m}$. standard time, passing from south-east to north-west, colours brilliant red and green. Two distinct explosions are reported to have been heard. After the first explosion a sinuous strcak remained visible until covered by clouds; the time of flight was from seven to eight seconds, and the apparent size about one-fourth that of the moon. Reports have been received from Listowel, Hastings, Beatrice, Belleville, Lakefield, Pembroke, Peterborough, Kings ton, Deseronto, Lindsay, and Huntingdon, all substantially agreeing as to course, size, \&c. ; it passed two or three miles south of Belleville, and about the same distance north of Lindsay."

Toronto, December 16,1887 .

\section{The Electrification of the Air.}

IN writing upon the electrical condition of the Peak of Teneriffe, the Hon. Ralph Abercrombie (NATURE, vol, xxxvii. p. $3 \mathrm{I}$ ), begins by stating that "the limited number of observations on atmospheric electricity which have been already made all point, with one exception, to a normal positive difference of potential between a point some few feet above the earth and the ground itself ;" and farther on he writes: "the electrical conditions of the Peak of Teneriffe [the one exception] were the same as in every other part of the world." As similar statements still find their way into text-books and treatises on electricity and meteorology, I trust you will permit me to point out that, unless a very special m: aning be attached to the word "normal," this generalization is decidedly too wide.

In a paper read at the Aberdeen meeting of the British Association in 1885 (printed Phil. Mag., November 1885), I pointed out that, in Madras at least, a negative electrification of the air was a normal, and not an abnormal, condition for many hours of the day at certain seasons of the year. Observations since taken have entirely confirmed the opinion that with a hot, dry, west wind the air at Madras is usually negatively electrified, and often to a very high potential.

With regard to observations made on mountains in the tropics, though perhaps hardly within what Mr. Abercromby terms "the zone of constant electrical discharge," I would venture to call his attention to a short paper on observations made on the top of Dodabetta ( 8642 feet) in the Transactiors of the Royal Society of Edinburgh, vol. xxxii. p. 583 .

I may add that during the periods of incessant discharges of sheet lightning which we often experience here the electrification of the air is sometimes positive and at other times negative, but generally positive.

Madras Christian College, Madras, December I4, 1887.

\section{Wind Force at Sea.}

PROF. WALDo, in the Amirican Metecrological Journal for October, recommends the use of instruments for determining the velocity of the wind at sea. In a paper read before the Meteorological Society, I discussed the comparative results, obtained from a great number of observations under all conditions at sea, between two very simple and small anemometers, showing that, although the two instruments were on entirely different principles, the results obtained differed only by about ro per cent. In a paper read in March last before the Meteorological Society, "Notes on taking Obscrvations at Sea, \&c.," I again urged the desirability of observers using some form of anemometer, so that more uniform results could be obtained, and I gave a table for correcting the apparent velocity of the wind as registered by the instrument for the speed of the ship and for aberration.

For instance, at the present time you may have two sailingships close together, one carrying top-gallant saile, the other only reefed top-sails, and the wind will be logged accordingly. Again, two steamers going in opposite directions are very likely to ex. perience apparently different wind velocities, and the senses of officers in steamers are not so acute for detecting differences in wind velocities as are those of officers in sailing-ships. The use of instruments would eliminate these errors.

With instruments similar to those I use-the cuefficient of friction of which is slight-the relative velocity of the wind may be obtained fairly accurately ; and I contend that this is of more importance than the chance there is of obtaining the estimated true velocity; and, I may add, the trouble attending the use of these instruments is small.

There are two other subjects which, up to the present, have received little attention at sea, viz. the registration of rainfall and the electrical condition of the atmosphere. Observations on both could easily be carried out on board some ships, and the observations would be both valuable and interesting.

DAVID WILSON-BARKER.

\section{A Troublesome Parasite of a Brittle-Starfish.}

IN a valualle work on certain parasitic Crustacea ("Contributions à l'Etude des Bopyriens," p. 181), Prof. A. Giard and J. Bonnier have done me the honour of calling attention to my discovery of a Copepod (?) which lives in the body of an Ophiuran, Amthiura squmata. They regard the mutual relationship of the Copepod and the Ophitran as an instance of the castration of the host by the parasite. Although all my observations indicate the correctness of some such an interpretation, I failed to recognize it as a fact until after they had pointed it out. The explanation seerns a possible one, and is provisionally accepted, with a few modifications, as the best as far as research has gone. The modifications are importnnt.

The state of knowledge of the subject is as follows. Ova and young of a Crustacean are found in the body of an American brittle-star, identified as Amflizura squamati. In some in stances an adult Crustacean was also found in the same place. When these ova, young, or adults are found parasitic in the Amphiura, the remains of the ovary of the host appear as an amorphous mass, and there is no possibility of future young of the Amphiura in the brood sac, since the ova have been destroyed.

The conclusion seems inevitable, for obscrvations indicate that the mother Crustacean makes her way somehow into the body of the host (Amphiura), then affects the brittle-star so that the young of the host will not clevelop, after which she leaves packets of ova to mature in the sacs where normally young Amphiuræ would develop. It thus happens that the products of the ovary of the host are clestroyed before the Crustacean ova are developed, or while they are in an early stage of cleavage. Consequently it is legitimate to conclude that if the ova of the host is destroyed it may be done by the aiult Crustacean.

If Trof. Giard and Bonnier are right in their interpretation that this is an instance of parasitic castration, as I think they are, we possibly have an interesting case of a parasite destroying the reproductive powers of the host for the future grod of her own offspring. Such a condition of things is unique, and among Ophiurans the writer recalls but the single instance of the present case of Amphiura. The case of the Crustacean and its brittle star hr st secms to differ from that of Entoniscus in that in the ore instance the destruction of the cvary may be of advantage to the parasite, while in the other the destruction or 